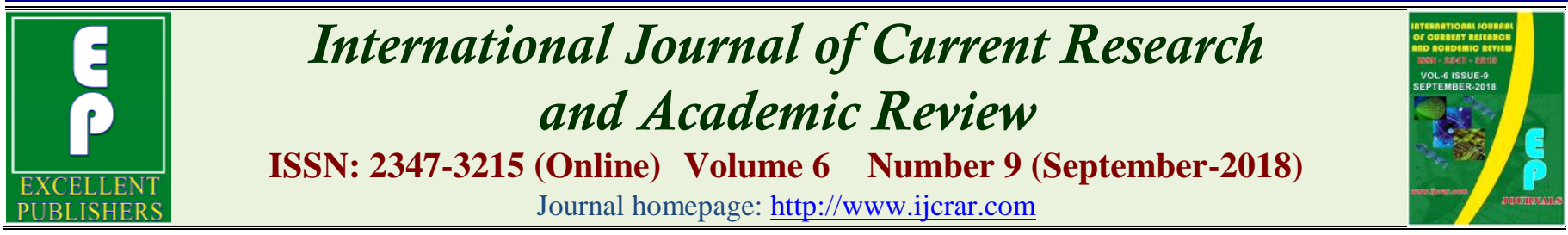

doi: https://doi.org/10.20546/ijcrar.2018.609.007

\title{
Production of Tuna (Opuntia ficus-indica) Wine by Alcoholic Fermentation for Industrial Processing
}

\author{
J. Guerrero', M. Parada ${ }^{2}$, V. Tapia ${ }^{2}$ and S. Vallejo ${ }^{2 *}$ \\ ${ }^{1}$ Investigador Facultad de Ciencias Ingeniería Química ESPOCH \\ ${ }^{2}$ Docentes Investigadores ESPOCH \\ *Corresponding author
}

\section{Abstract}

The main objective of this study to obtain tuna wine (Opuntia ficus-indica) in general, in the first instance the NTE 1750 regulation was used to establish the sample size of fruit in the experimental development; with one of which, the procedures are directed to the production of wine of fruits and traditional wine; by means of the fermentation process when using types of yeast: Saccharomyces cerevisiae and Saccharomyces cerevisiae var. Bayanus. The raw material was analyzed under physicochemical parameters according to NTE 978, resulting in a defective percentage: $1.93 \%$, ${ }^{\circ}$ Brix: $15 \%$, pulp content: $54.33 \%$, and titratable acidity (citric acid): $0.20 \%$, medium size and extra grade; and microbiological parameters according to NTE 2337, yielding results for molds and yeasts: $20 \mathrm{CFU} / \mathrm{g}$ and Mesophilic Aerobics: $70 \mathrm{CFU} / \mathrm{g}$, thus accepting processing. An alcoholic strength close to $12 \%(\mathrm{v} / \mathrm{v})$ and a $\mathrm{pH}: 3.5$ in the final product is adjusted to $21^{\circ}$ Brix and a titratable acidity of $0.55 \%$. The end of the fermentative process at $20^{\circ} \mathrm{C}$ is established through daily readings of ${ }^{\circ} \mathrm{Brix}$, thus the first fermentation test lasts for 8 days and the second for 10 days. The resulting fermented musts are clarified in the following dosages: $60 \mathrm{~g} / \mathrm{hL}$ of bentonite, $8 \mathrm{~g} / \mathrm{hL}$ of gelatin and $40 \mathrm{~g} / \mathrm{hL}$ of bentonite, $8 \mathrm{~g} / \mathrm{hL}$ of gelatin with an execution time of 8 days and 6 days respectively. Through a sensory analysis by the affective method, a general acceptance of $22 \%, 65 \%$ and $17 \%$ is obtained for the first and second tests, and the third corresponds to the control sample, is characterized by the wine with the highest acceptance according to the NTE standard. 374, obtaining: Alcohol 11.87\% (v / v), Volatile acidity (acetic acid): $1.31 \mathrm{~g} / \mathrm{l}$; Total acidity (tartaric acid): $6.23 \mathrm{~g} / \mathrm{L}$; Total sulfur dioxide: $381.22 \mathrm{mg} / \mathrm{L}$; Methanol: <2.00 mg / L and sugar content: $6.40 \mathrm{~g} / \mathrm{L}$; therefore its production is established; Based on the time of production and content of residual sugars, it is classified as a young and dry wine according to the NTE INEN 0338 standard.
\end{abstract}

\section{Article Info}

Accepted: 25 August 2018

Available Online: 20 September 2018

\section{Keywords \\ Tuna (Opuntia ficus-indica), Tuna Wine, Process Design, Fermentation Trials, Physicochemical \\ Characterization, Sensory Analysis, Yeast (Saccharomyces cerevisiae), Yeast (Saccharomyces cerevisiae var. Bayanus)}

\section{Introduction}

For this reason and that one of the plants that resist the climatic and arid conditions in Ecuador is the nopal, the idea of cultivating and processing it, especially its fruit, emerges there.
The tuna is an edible fruit that comes from the cactus plant, ovoid, fleshy, spherical pulp, whose dimensions and hue change according to the variety (NTE INEN, 1978); It has a skin full of thorns but its pulp has a pleasant and sweet flavor. The existing varieties of prickly pear belonging to the species Opuntia ficus- 
indica, differ in the coloration of the peel and the pulp of the ripe fruit. The difference between the varieties lies in the coloration of the fruit and the presence or absence of thorns (Ponce Guevara-Ana jasmine and Vela LomasDanilo Tito, 2010).

In Ecuador, only four varieties thrive: yellow without thorns; yellow, white and wild these three with thorns (https://www.elcomercio.com/actualidad/negoCios/tunafour-varieties-se-roducen.html).

The industrialization and / or processing of the tuna has a great future, since it supposes an advantage in the local market as opposed to the direct sale of this fruit as fodder or as fresh fruit for direct consumption respectively; that allows to develop food products, so you want to venture into the production of prickly pear wine.

Wine as defined "It is the alcoholic beverage obtained by complete or partial fermentation of fresh grapes or grape must" (NTE INEN). But we must note that the grape is a fruit of special climatic requirements, therefore, it can not be grown in any area of the planet. Well, nothing prevents obtaining a product equivalent to wine, from fruits that thrive in regions where the grape is not cultivable; thus, in many legislations the term fruit wine was established, with the only requirement to specify the name of the fruit or fruits used for its elaboration.

As it appreciates (Gonzáles, 2017), it is an irrefutable truth the existence of a wide range of fruits that with a simple technology can be transformed into wine of excellent quality. Then we specify the fruit wine as an "alcoholic beverage obtained through complete fermentation or partial of fruit or must of fruit" (NTE INEN). Taking into account the previous thing, we established to the wine of tuna like an alcoholic beverage obtained from the fermentation of the must of this fruit that thanks to the content of sugars and acids makes it susceptible to alcoholic fermentation.

\section{Materials and Methods}

It is fundamental to express that the methodology to be used is not oriented to the elaboration of fruit liquor by maceration in hot water or distillation as you might think; the procedures are directed to the production of tuna wine through the process of alcoholic fermentation from the sugars present in the fruit and sugars that may or may not be added, as well as other operations and procedures established in the production of wine from fruits and wine traditional.
The sample of raw material, intermediate products and tuna wine are analyzed under physicochemical, microbiological and sensory parameters according to corresponding regulations, to ensure the quality of the final product.

\section{Sampling and categorization of the raw material}

We proceed to the sampling of the white variety tuna, under the terminology, the general provisions and the procedure, contemplated in the regulation NTE INEN 1750: 1994 Vegetables and Fresh Fruits. Sampling. To extract the elementary samples from the harvest lot, we proceed to list the boxes as they are filled and transported to the market for sale; as the regulations express these boxes are considered as packaged or packaged products that must be taken at random according to what is indicated in the following table.

The three elementary samples are transferred to the laboratory for processing, then the 3 boxes are mixed to form the global sample. The dimensions of the fruit and its weight are taken in order to catalog it by its size and later its degree based on inspection.

\section{Manufacturing process}

\section{Obtaining prickly must}

The global sample is inspected under the general requirements, quality tolerance ranges described in the NTE INEN 1978: 2009 Fresh Fruits standard. Tuna. Requirements The inspection is carried out to select the fruit in good condition, and determine the percentage of defective, the results indicate whether the fruit is suitable for processing, based on the size of the overall sample () of $30.61 \mathrm{Kg}$ is removed $0,59 \mathrm{Kg}$ of futra in poor condition ().

$\%$ Def $=\frac{F m}{F i} * 100$

$\%$ Def $=1,93$

During the harvest in the plantations the adaptation of the tuna operation consisting of cleaning the fruit and eliminating the thorns is carried out, however, it may still contain some kind of residue such as dust, remains of thorns, etc., so it is necessary cleaning. The sample for laboratory analysis is processed to calculate the pulp content, according to the regulations for prickly pear the following formula is used. 
Contenido de pulpa $=\frac{\text { Masa de pulpa }}{\text { Masa del fruto }} * 100$

Contenido de pulpa $=\frac{11,92}{21,94} * 100=54,33 \%$

Subsequent to extracting the pulp, this is destined to the pulping operation with the objective of separating the seeds, the obtained fluid is called hereafter as prickly must; Once this is done, a sample is taken to perform the physicochemical and microbiological characterization.

\section{Physicochemical and microbiological characterization of the raw material}

\section{Fermentation tests}

To the must of prickly pear must be made a series of adjustments prior to the fermentation process, the first corresponds to add 0.21 grams of sodium metabisulfite to this is known as sulphited taking into account the maximum limits allowed for the use of this chemical in standards and technical documents of OIV, leaving it at rest for 24 hours. After rest, sucrose and citric acid are added in calculated amounts taking into account that it is desired to reach twice the initial volume, that is to say, must completely corrected; with addition of water to facilitate the mixing thereof and the mobility of the yeast during fermentation.

The ${ }^{\circ}$ Brix are determined by a refractometer that yields a value of 15 for the prickly must, but according to the alcohol tables it is probably not enough to reach the alcoholic degree close to $12 \% \mathrm{v} / \mathrm{v}$ desired in the tuna wine.

So we proceed to adjust the must to $21^{\circ}$ Brix adding sucrose. The must must have a titratable acidity of $0.55 \%$, the optimum value for the development of Saccharomyces cerevisiae yeasts in general (PadillaConcepción, 2004).

The fermentative process is monitored by daily readings of ${ }^{\circ}$ Brix; When it is concluded when said readings do not change during the time, the fermentation sludge is deposited in the bottom of the container and $\mathrm{CO}_{2}$ is no longer observed.

Once the fermentation is complete, the wine is uncovered, which consists of separating the fermented must from its lees or sludge.

\section{Clarification tests}

The fermented must differs tenuously from being a wine because it presents a slight turbidity, for this it is necessary to execute a clarification and transfer as the last step prior to packaging. The turbidity of each fermented must according to the yeast used is analyzed. For each fermented must from the two fermentation tests four samples of $100 \mathrm{~mL}$ are taken, where bentonite and later gelatine dosages will be applied.

To identify the best dosage to use both bentonite and gelatin, each of the clarification tests are evaluated with the help of a professional experienced in enology and mixology, who through a sensory analysis evaluates them by means of a tab. to score. Each test is coded according to the bentonite / gelatin dosage used as a reference and presented to the evaluating professional. The clarification test whose score is greater will be added to the rest of the volume of the fermented must and its duplicate.

With the established dosages we proceed to completely treat the fermented must following the necessary time for the clarification to be carried out.

We evaluated the turbidity of the prickly pear wines from the two fermentation trials whose results were 3.8 and 3.2 NTU for the first and second trials.

At the end of the clarification, the biomass corresponding to the material removed by the clarifying agents has been deposited in the bottom of the containers, then proceeds to separate the tuna wine from these sludges.

Validation of the process through sensory analysis and the physical-chemical characterization of the tuna wine

To carry out the sensory analysis, the affective method is used, which allows selecting a group of untrained people called "Affective Judges" but who are considered as potential or immediate consumers of the product (Espinosa-Julia, 2007).

The test is carried out with the collaboration of 101 affective judges. Each one has at its disposal three samples labeled with their respective coding and accompanied by a glass of water. We proceed to explain to the judges the kind of product they are going to evaluate, the way to do it and how to fill out the survey according to the model of the same. 
After the survey stage, the data are tabulated and the results obtained from the statistical point of view are analyzed with the chi-square test to verify if there is a relationship between the samples and the response levels with respect to each parameter of the test. Interest (Color, Aroma and Taste).

Although according to the results of the sensorial analysis by affective judges, the two wines elaborated in the laboratory in a technical way present a greater acceptance with respect to the third one; it is necessary to establish which one of them is analyzed in order to check compliance with current regulations and validate the design of manufacture.Then to validate the process of making the physicochemical characterization of the tuna wine from the second trial of fermentation that is, the one where Saccharomyces cerevisiae var. Bayanus; The results are shown below:

\section{Results and Discussion}

The national regulation NTE INEN 1750 is used, establishing 3 elementary samples corresponding to 9.78 $\mathrm{Kg}, 10.2 \mathrm{Kg}$ and 10.63 , the mixture of which forms the overall sample $30.61 \mathrm{Kg}$, requiring laboratory-level processing an amount of $21.94 \mathrm{Kg}$ what is called as sample for analysis. Ten units of the global sample are taken at random to measure their dimensions and weights, according to the values thrown the average mass value is $0.102 \mathrm{Kg}$, length of $68.5 \mathrm{~mm}$ and diameter of $49.5 \mathrm{~mm}$. The global sample is inspected, giving a value of $0.59 \mathrm{~kg}$ of fruit in poor condition, therefore a defective percentage of $1.93 \%$.

The clean and well-maintained global sample corresponds to $29.94 \mathrm{Kg}$ of which only $21.94 \mathrm{Kg}$ (sample for laboratory analysis) is required to be subjected to peeling obtaining $10,02 \mathrm{Kg}$ of skin and $11.92 \mathrm{Kg}$ of pulp with an operating yield of $54.33 \%$ which corresponds to the pulp content one of the parameters of the physicochemical characterization.For the first fermentation test the fermentation lasts for 8 days, while in the second 10 days.

In the first test during the discovery, $2.40 \mathrm{~L}$ of fermented must and $1.38 \mathrm{~L}$ of lees are obtained; in the second test the fermented must $3.16 \mathrm{~L}$ and $0.675 \mathrm{~L}$ of lees with an alcoholic degree achieved dry to $12 \%(\mathrm{v} / \mathrm{v})$ in the two tests.

The optimal dosage of clarifiers for the fermented must from the first fermentation test is $60 \mathrm{~g} / \mathrm{hL}$ of bentonite and $8 \mathrm{~g} / \mathrm{hL}$ of gelatin, while for the second it is $40 \mathrm{~g} /$ $\mathrm{hL}$ of bentonite and $8 \mathrm{~g} / \mathrm{hL}$ of gelatin taking an execution time of 8 days and 6 days respectively; when evaluating the turbidity at the end of the clarification whose values are 3.8 and 3.2 NTU respectively.

For the first test where 2,4 $\mathrm{L}$ of fermented must is started when clarifying and transferring, $2.33 \mathrm{~L}$ is obtained, while for the second test $3.16 \mathrm{~L}$ of fermented must is obtained, it is obtained after clarification and transfer 3.1 $\mathrm{L}$ of tuna wine.

We establish based on the average value of weight, diameter and length of the fruit a caliber or medium size according to the national regulation NTE INEN 1978, in addition to extra grade because the quality tolerance establishes a maximum of 5\% of defects for this qualification The physical-chemical characterization of the raw material has been affected by the physicalchemical requirements by the national standard for tuna in the permitted ranges.

Likewise, the microbiological analysis of the parameters: Molds and Yeasts, and Mesophilic Aerobics gives compliance to these parameters in its Table 3, taking as reference the NTE INEN 2337 standard.

According to the ${ }^{\circ}$ Brix of the must of prickly pear and using as a reference tables of probable alcohol it is observed that it is not enough to reach the alcoholic degree close to $12 \% \mathrm{v} / \mathrm{v}$ that you want in the wine of prickly pear so you proceed to adjust the must to $21^{\circ}$ Brix adding 2,295 $\mathrm{Kg}$ of sucrose; this is because a wine whose alcohol content is greater than $10 \%(\mathrm{v} / \mathrm{v})$ and $\mathrm{ph}$ : 3.5-4 protects it from certain alterations and gives it longevity (http://urbinavinos.blogspot.com/2013/10/metabisulfitopotasico-so2-composicion.html).

The must acidity should be adjusted to a titratable acidity of $0.55 \%$, the optimum value for the development of the yeasts of the genus Saccharomyces cerevisiae in general (Padilla, 2004), adding $0.06 \mathrm{~kg}$ of citric acid. Finally, water is added until it reaches twice the volume of the prickly must coming from the pulped one.

Two fermentation tests are carried out in 4 liters of corrected must each, using Saccharomyces cerevisiae in a dosage of $1 \mathrm{~g} / \mathrm{L}$, efficient dosage in previous trials and Saccharomyces cerevisiae var. Bayanus in dosage of $0.25 \mathrm{~g} \mathrm{/} \mathrm{L} \mathrm{recommended} \mathrm{by} \mathrm{the} \mathrm{manufacturer;} \mathrm{with}$ duplicates for each test at a temperature of $20^{\circ} \mathrm{C}$. 
Table.1 Number of incremental samples for packaged or packaged products

\begin{tabular}{|c|c|}
\hline $\begin{array}{c}\text { Number of bags, boxes, } \\
\text { etc., with similar } \\
\text { characteristics in the lot }\end{array}$ & $\begin{array}{c}\text { Number of bags, boxes, } \\
\text { etc., to be extracted, } \\
\text { constituting each one an } \\
\text { elementary sample }\end{array}$ \\
\hline$\leq \mathbf{5 0}$ & $\mathbf{3}$ \\
$51-90$ & 5 \\
$91-150$ & 8 \\
$151-280$ & 13 \\
$281-500$ & 20 \\
$501-1200$ & 32 (minimum) \\
\hline
\end{tabular}

Table.2 Determination of the size or size of the fruit

\begin{tabular}{|l|l|l|l|}
\hline Samples & Time $(\mathbf{g})$ & $\begin{array}{l}\text { Longitud } \\
(\mathbf{m m})\end{array}$ & $\begin{array}{l}\text { Diameter } \\
(\mathbf{m m})\end{array}$ \\
\hline 1 & 116 & 79 & 51 \\
\hline 2 & 104 & 67,5 & 51 \\
\hline 3 & 85 & 60,1 & 47 \\
\hline 4 & 104 & 80 & 45 \\
\hline 5 & 134 & 76 & 53,5 \\
\hline 6 & 118 & 78 & 58 \\
\hline 7 & 94 & 64,9 & 48 \\
\hline 8 & 100 & 69 & 47 \\
\hline 9 & 98 & 68 & 54,2 \\
\hline 10 & 74 & 64 & 42,5 \\
\hline Average & $\mathbf{1 0 2}$ & $\mathbf{6 8 , 5}$ & $\mathbf{4 9 , 5}$ \\
\hline
\end{tabular}

Table.3 Results of the physicochemical and microbiological characterization of the raw material

\begin{tabular}{|c|c|c|c|c|c|}
\hline Parameter & Minimum & Maximum & Unity & Testing method & Result \\
\hline Pulp Content & 50 & ---- & $\%$ & & 54,33 \\
\hline $\operatorname{SST}_{\left(20^{\circ} \mathrm{C}\right)}$ & 10 & ---- & ${ }^{\circ}$ Brix & Ref. NTE INEN 380 & 15,00 \\
\hline $\begin{array}{l}\text { Titratable } \\
\text { acidity } \\
\text { (Citric Acid) }\end{array}$ & ---- & 1,08 & $\%$ & Ref. NTE INEN 381 & $\mathbf{0 , 2 0}$ \\
\hline$\overline{\mathrm{pH}}\left(25^{\circ} \mathrm{C}\right)$ & ---- & ---- & ---- & Ref. NTE-ISO 1842 & 6,33 \\
\hline Density $\left(20^{\circ} \mathrm{C}\right)$ & ---- & --- & $\mathrm{Kg} / \mathrm{L}$ & Laboratory manual & 1,04 \\
\hline Viscosity $\left(19.7^{\circ} \mathrm{C}\right)$ & ---- & ---- & $\mathrm{mPa} \cdot \mathrm{s}$ & Laboratory manual & 108,20 \\
\hline $\begin{array}{l}\text { Molds and } \\
\text { yeasts }\end{array}$ & ---- & $1,0 \times 10^{3}$ & $\mathrm{UFC} / \mathrm{g}$ & INEN 1529-10 & 20 \\
\hline $\begin{array}{l}\text { Aerobios } \\
\text { Mesófilos }\end{array}$ & ---- & $1,0 \times 10^{3}$ & $\mathrm{UFC} / \mathrm{g}$ & INEN 1529-5 & 70 \\
\hline
\end{tabular}


Table.4 Results physicochemical characterization of adjusted wort

\begin{tabular}{|l|c|c|}
\hline Parameter & Value & Units \\
\hline${ }^{\circ}$ Brix & 21,00 & - \\
\hline $\mathrm{pH}$ & 4,01 & - \\
\hline Density ${ }_{\left(20^{\circ} \mathrm{C}\right)}$ & 1,10 & $\mathrm{Kg} / \mathrm{L}$ \\
\hline Viscosity $_{\left(19.7^{\circ} \mathrm{C}\right)}$ & 107,80 & $\mathrm{mPa} . \mathrm{s}$ \\
\hline $\mathrm{Cp}$ & 4,019 & $\mathrm{KJ} / \mathrm{Kg}^{\circ} \mathrm{C}$ \\
\hline
\end{tabular}

Table.5 Conditions for fermentation tests and their duplicates

\begin{tabular}{|l|l|l|}
\hline \multirow{2}{*}{ Terms } & \multicolumn{2}{c|}{ Fermentation tests } \\
\cline { 2 - 3 } & First essay & Second trial \\
\hline Type of yeast & Saccharomyces cerevisiae & $\begin{array}{l}\text { Saccharomyces cerevisiae } \\
\text { There is. bayanus }\end{array}$ \\
\hline Yeast dosage & $1 \mathrm{~g} / \mathrm{L}$ & $0,25 \mathrm{~g} / \mathrm{L}$ \\
\hline Fermentation temperature & $20^{\circ} \mathrm{C}$ & $20^{\circ} \mathrm{C}$ \\
\hline Titratable acidity (citric acid) & $0,55 \%$ & $0,55 \%$ \\
\hline $\mathrm{pH}$ & 4,03 & 4,03 \\
\hline${ }^{\circ}$ Brix & $21 \%$ & $21 \%$ \\
\hline
\end{tabular}

Table.6 Clarification tests with bentonite (dosages)

\begin{tabular}{|c|c|c|c|c|}
\hline Tests & g/hL & g/L & g/100 $\mathbf{~ m L}$ & $\begin{array}{l}\text { mL of Solution } \\
\text { Bentonite }(\mathbf{2 0 \%})\end{array}$ \\
\hline White & ----- & ------ & ------ & -------- \\
\hline 1 & 20 & 0,2 & 0,02 & 0,1 \\
\hline 2 & 40 & 0,4 & 0,04 & 0,2 \\
\hline 3 & 60 & 0,6 & 0,06 & 0,3 \\
\hline
\end{tabular}

Table.7 Gelatin clarification tests (dosages)

\begin{tabular}{|c|c|c|c|c|}
\hline Test & g/hL & g/L & g/100mL & $\begin{array}{c}\text { mL of solution } \\
\text { of gelatin (10\%) }\end{array}$ \\
\hline White & --------- & ------ \\
\hline $1,2,3$ & 8 & 0,08 & 0,008 & 0,08 \\
\hline
\end{tabular}

Table.8 Results of the evaluations of the clarification tests

\begin{tabular}{|l|l|l|l|l|}
\hline \multicolumn{5}{|c|}{ Fermented must from the first trial } \\
\hline Clarification tests & White & $\mathbf{2 0 / 8}$ & $\mathbf{4 0 / 8}$ & $\mathbf{6 0 / 8}$ \\
\hline Qualification & ----- & 51 & 65 & 69 \\
\hline \multicolumn{5}{|c|}{ Fermented must from the second trial } \\
\hline Clarification tests & White & $\mathbf{2 0 / 8}$ & $\mathbf{4 0 / 8}$ & $\mathbf{6 0 / 8}$ \\
\hline Qualification & ----- & 69 & 76 & 72 \\
\hline
\end{tabular}


Table.9 Dosing and time needed for clarification with bentonite

\begin{tabular}{|l|c|c|c|c|c|c|}
\hline & $\begin{array}{l}\text { Volume must } \\
\text { fermented (L) }\end{array}$ & $\mathbf{g} / \mathbf{h L}$ & $\mathbf{g} / \mathbf{L}$ & $\mathbf{g} / \mathbf{V}_{\mathbf{m f}}$ & $\mathbf{m L}$ solution & Time (days) \\
\hline First essay & 2,4 & 60 & 0,60 & 1,44 & 7,20 & 6 \\
\hline Second trial & 3,16 & 40 & 0,40 & 1,264 & 6,32 & 4 \\
\hline
\end{tabular}

Table.10 Dosage and time needed for clarification with gelatin

\begin{tabular}{|l|c|c|c|c|c|c|}
\hline & $\begin{array}{l}\text { Volume must } \\
\text { Fermented (L) }\end{array}$ & $\mathbf{g} / \mathbf{h L}$ & $\mathbf{g} / \mathbf{L}$ & $\mathbf{g} / \mathbf{V}_{\mathbf{m f}}$ & $\mathbf{m L}$ solution & Time (days) \\
\hline First essay & 2,4 & 8 & 0,08 & 0,192 & 1,92 & 3 \\
\hline Second trial & 3,16 & 8 & 0,08 & 0,2528 & 2,53 & 2 \\
\hline
\end{tabular}

Table.11 Coding for prickly pear wines to be evaluated by affective judges

\begin{tabular}{|l|l|c|}
\hline \multicolumn{1}{|c|}{ Origin } & \multicolumn{1}{|c|}{ Reference } & Code \\
\hline \multirow{2}{*}{ Laboratory-level tests } & Vinification yeast & $\mathbf{3 4 5 6}$ \\
\cline { 2 - 3 } & Baking Yeast & $\mathbf{7 8 9 2}$ \\
\hline Artesanal wine & Baking Yeast & $\mathbf{9 8 2 0}$ \\
\hline
\end{tabular}

Table.12 Results of the general acceptance level of affective judges

\begin{tabular}{|c|c|c|c|c|}
\hline Code & Frequency & Percentage & Valid percentage & Accumulated percentage \\
\hline $\mathbf{3 4 5 6}$ & 63 & 62,4 & 62,4 & 62,4 \\
\hline $\mathbf{7 8 9 2}$ & 20 & 20,8 & 20,8 & 83,2 \\
\hline $\mathbf{9 8 2 0}$ & 17 & 16,8 & 16,8 & 100,0 \\
\hline TOTAL & 101 & 100,0 & 100,0 & \\
\hline
\end{tabular}

Table.13 Chi-square test results parameter Color

\begin{tabular}{|l|c|c|}
\hline & Degrees of freedom & Value \\
\hline Pearson Chi-square & 4 & 14,89 \\
\hline Reason for similarities & 4 & 9,49 \\
\hline Number of valid cases & --- & 101 \\
\hline
\end{tabular}

Table.14 Chi-square test results Aroma parameter

\begin{tabular}{|l|c|c|}
\hline & Degrees of freedom & Value \\
\hline Pearson Chi-square & 4 & 8,96 \\
\hline Reason for similarities & 4 & 9,49 \\
\hline Number of valid cases & & 101 \\
\hline
\end{tabular}

Table.15 Results test chi-square parameter Flavor

\begin{tabular}{|l|c|c|}
\hline & Degrees of freedom & Value \\
\hline Pearson Chi-square & 4 & 3,41 \\
\hline Reason for similarities & 4 & 9,49 \\
\hline Number of valid cases & & 101 \\
\hline
\end{tabular}


Table.16 Results of the physicochemical characterization of the tuna wine

\begin{tabular}{|l|c|c|c|c|c|}
\hline Requirements & Unity & Minimum & Maximum & Testing method & Result \\
\hline Alcohol, volumetric fraction & $\%$ & 6,0 & ---- & NTE INE 360 & $\mathbf{1 1 , 8 7}$ \\
\hline $\begin{array}{l}\text { Volatile acidity, such as } \\
\text { acetic acid }\end{array}$ & $\mathrm{g} / \mathrm{L}$ & ---- & 1,5 & NTE INE 341 & $\mathbf{1 , 3 1}$ \\
\hline $\begin{array}{l}\text { Total acidity, such as tartaric } \\
\text { acid }\end{array}$ & $\mathrm{g} / \mathrm{L}$ & 3,5 & ---- & NTE INE 341 & $\mathbf{6 , 2 3}$ \\
\hline Total sulfur dioxide & $\mathrm{mg} / \mathrm{L}$ & ---- & 400,0 & NTE INE 356 & $\mathbf{3 8 1 , 2 2}$ \\
\hline Methanol & $\mathrm{mg} / \mathrm{L}$ & ---- & 1000,0 & NTE INE 347 & $<\mathbf{2 , 0 0}$ \\
\hline $\begin{array}{l}\text { Content of Sugars } \\
\text { Dry wine }\end{array}$ & $\mathrm{g} / \mathrm{L}$ & $\begin{array}{c}--- \\
\text { Semi-sweet wine }\end{array}$ & $\begin{array}{l}\mathbf{2 5 , 0} \\
50,0\end{array}$ & Fehling & $\mathbf{6 , 4 0}$ \\
Sweet wine & & 50,1 & ---- & & \\
\hline
\end{tabular}

Source: (NTE INEN 374 (3R), 2016, p.2)

Graph.1 Description of methods and techniques used

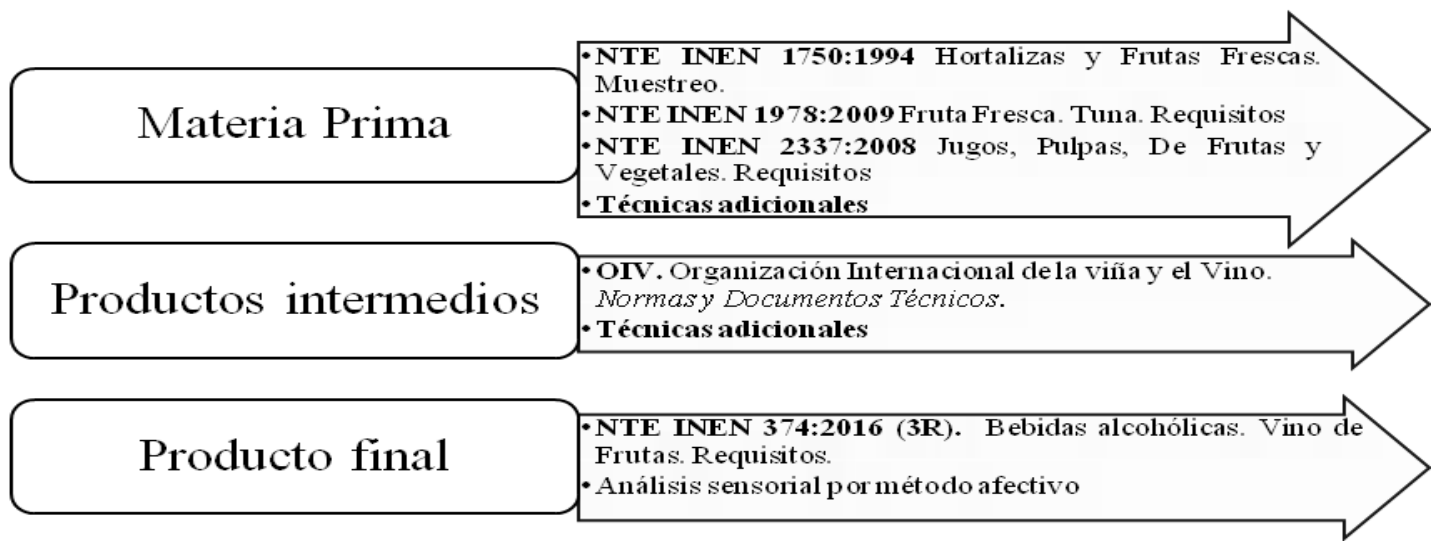

Graph.2 Readings of ${ }^{\circ}$ Brix for the first fermentation trialand its duplication

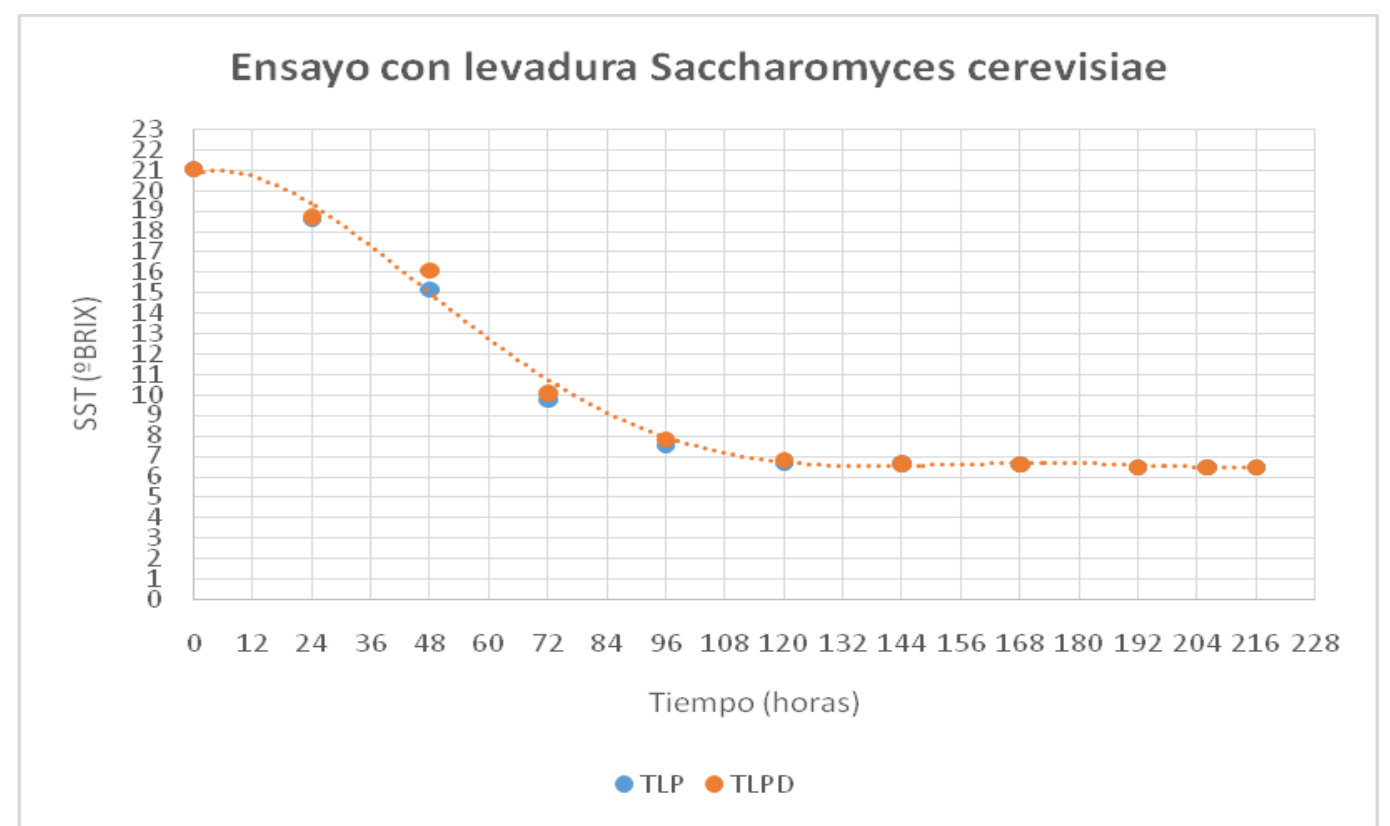


Graph.3 Readings of ${ }^{\circ}$ Brix for the second fermentation trial

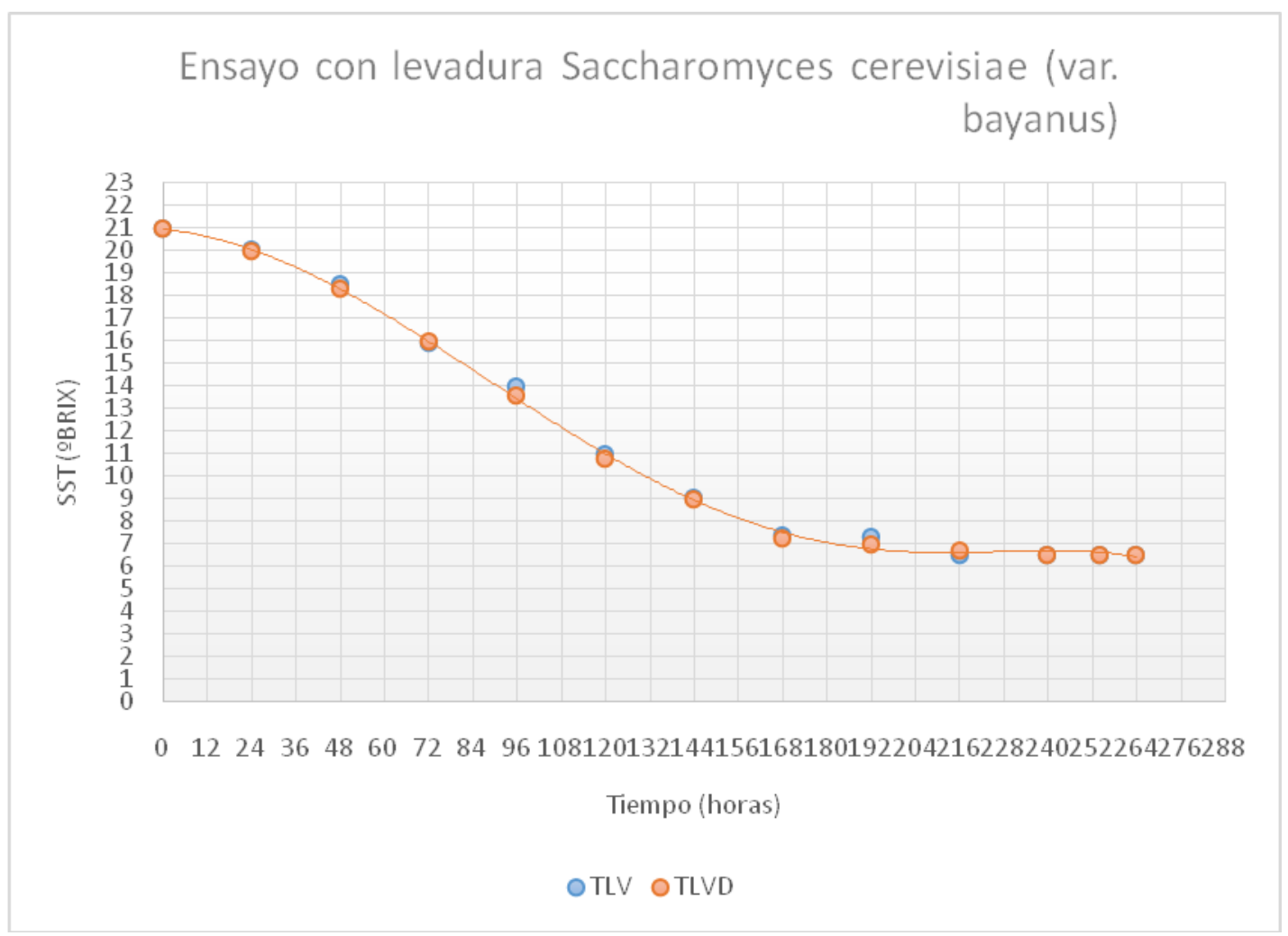

Graph.4 Overall percentage of acceptance by affective judges

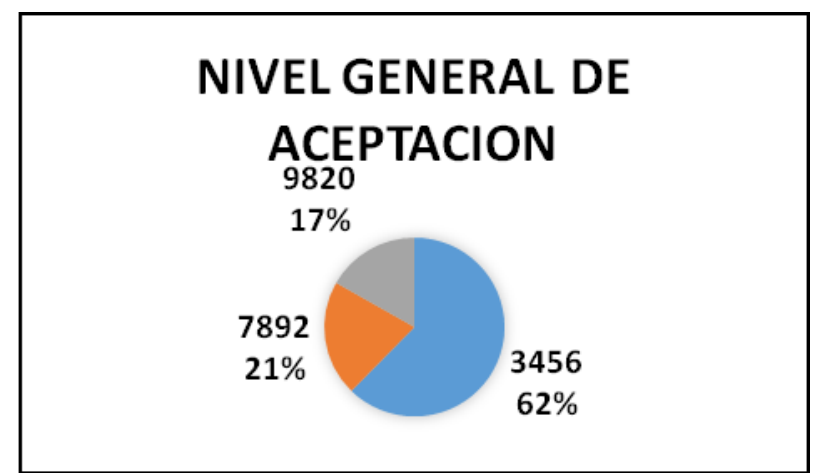

For the first test of fermentation and its duplication you can observe that in the first 24 hours the coupling of the yeast to the medium occurs, from there the fermentative process until the fourth day enters a vigorous phase with remarkable reductions in the readings; from the fifth to the seventh day the fermentation enters in slow phase tending to not vary from the eighth day, while for the second test and its duplicate the first 24 hours the yeast adjusts to the must, from there the fermentative process until the sixth day enters a vigorous phase with remarkable reductions in the readings, from the sixth to the ninth day the fermentation enters in slow phase tending to not vary from the tenth day. In the discovery of the second fermentation test the overall yield is $79 \%$ and 98 ,

Regarding turbidity, although this parameter is not established by national or foreign regulations because it depends a lot on the nature of the wine, the variety of the fruit used among other things, however, the acceptable turbidity value for a white wine The young man oscillates between 2.5 to 4 NTU (Wagner, 2018), the tuna wine being found in this characteristic range suitable for commercialization. 
For the fermented must of the first test, when performing the clarification and transfer, a yield of $96.72 \%$ is obtained; while for the second trial a yield of $97.83 \%$. A $95 \%$ confidence or $5 \%$ risk a dependence between the sample and the level of response (I like it, I do not like it, etc.) for the color parameter ; this agrees because each sample during its production has gone through a different clarification stage; Regarding aroma preferences, it is verified that there is no dependence between the sample and the level of response as well as for the flavor parameter, this agrees since all the samples correspond to tuna wine and not to wines of different fruits.

Finally the physicochemical characterization of the tuna wine of greater acceptance the results comply with the parameters indicated in the NTE INEN 374 standard, thus establishing the production and marketing of the product. The tuna wine corresponds to a fruit wine and based on time estimated of its production per batch of one month and the content of residual sugars of $6.4 \mathrm{~g} / \mathrm{L}$ is classified as a young wine of dry type according to the national regulation NTE INEN 0338.

It was obtained from prickly pear wine according to a methodology related to the elaboration of wine of fruits and traditional wine, through an experimental development at laboratory level the following operations are established: reception of the raw material in the required quantity, approval of the processing of the fruit through the physicochemical characterization of a sample, inspection and selection, washing, peeling, pulping, preparation and adjustment of the must, alcoholic fermentation and discovery, clarification and transfer, packaging and labeling.

When carrying out the physicochemical characterization of the raw material, a white variety for oenological practice, the following results are obtained: Brix: 15, pulp content: $54.33 \%$, and titratable acidity as citric acid: $0.20 \%$; these values are within the ranges allowed by the NTE INEN 1978: 2009 Fresh Fruits standard. Tuna. Requirements, so we can say that the fruit not only complies with these regulations, but also that its quality is usable for industrial processing.

The elaboration process is validated by a sensory analysis by the affective method with the use of the acceptance tests for the tuna wines from the first fermentation trial, the second fermentation trial and the company, obtaining a general acceptance of $63 \%, 22 \%$ and $17 \%$ respectively; Finally, the physicochemical characterization of the tuna wine with the highest acceptance according to the NTE INEN 374: 2016 alcoholic beverages. Fruit wine Requirements, obtaining as results: Alcohol 11.87\% (v / v), Volatile acidity, such as acetic acid $1.31 \mathrm{~g} / \mathrm{L}$; Total acidity, as tartaric acid $6.23 \mathrm{~g} / \mathrm{L}$; Total sulfur dioxide $381.22 \mathrm{mg} /$ L; Methanol: <2.00 mg / L and Sugar Content $6.40 \mathrm{~g} /$ $\mathrm{L}$; therefore the production and commercialization of the product is established.

Once the manufacturing process of the tuna wine is established, which complies with the Ecuadorian regulations for fruit wine; As well as its acceptance in the sensory analysis, the variables and their control points of direct influence are identified in the following parameters: For the fruit: ${ }^{\circ}$ Brix: 15 , yield in pulp, Titratable acidity as citric acid; In alcoholic fermentation: Temperature, $\mathrm{pH}$, Time, ${ }^{\circ}$ Brix, inoculum dosage; in clarification: time, dosing of clarifiers, and for the final product: alcohol content, $\mathrm{pH}$

\section{Acknowledgement}

I express my deepest gratitude to him. Pedro Badillo, as well as the company VITA TUNA for their collaboration in the field tasks, and the contribution of all the necessary information for the development of the present investigation.

\section{References}

Espinosa-Julia. Sensory Evaluation of Food. HavanaCuba: University; 2007

Gonzáles, Marcos. Artisanal Elaboration of Fruit Wine. [Internet]. 1st ed. Venezuela: Lulu Pres. IncEditorial; 2012 [updated 2012; quoted 15 August 2017]. Available

at: https://books.google.com.ec/books?id=a9N6PxzJ R2 QC \& printsec = fronTcover\&dq=Elaboraci\%C3\%B3n+Artesanal+de + Vino+de+Frutas.\&hl $=$ es\&sa $=X \& v e d=0$ ahUKEwiv mZWq7rrdAhWts1kKHY6sDHIQ6AEIJTAA\#v=sn ippet\&q=Elaboraci\%C3\%B3n\%20Artesanal\%20de $\% 20$ Vino $\% 20 \mathrm{de} \% 20$ Frutas. $\& \mathrm{f}=$ false

NTE INEN 0338. Alcoholic beverages. Definitions.

NTE INEN, 1978. Fresh Fruits. Tuna. Requirements

Padilla-Concepción. Obtaining liquors and wines from the tuna of Duraznillo (Opuntia leucotricha). Mexico: Agrarian Autonomous University "Antonio Narro"; 2004

Ponce Guevara-Ana jasmine and Vela Lomas-Danilo Tito. Post-harvest handling of two Varieties of prickly pear (Opuntia ficus-indica) produced in the 
chota valley. [Undergraduate Thesis] Ibarra: Universidad Técnica del Norte; 2010

The Commerce. Tuna four varieties of prickly pear are produced in the country. [Internet]. 2015 [cited June 20 , 2017]; Available

at: https://www.elcomercio.com/actualidad/negoCios/tu na-four-varieties-se-roducen.html

Urvina Vinos Blog. Metabisulfito de potasio, composición, dosis y modo de empleo. [Internet] 2013. [Consulta: 17 de Agosto de 2017.].

\section{How to cite this article:}

Guerrero J., M. Parada, V. Tapia and Vallejo S. 2018. Production of Tuna (Opuntia ficus-indica) Wine by Alcoholic Fermentation for Industrial Processing. Int.J.Curr.Res.Aca.Rev. 6(9), 72-82.

doi: https://doi.org/10.20546/ijcrar.2018.609.007
Disponible en: http://urbinavinos.blogspot.com/2013/10/metabisulf ito-potasico-so2-composicion.html.

Wagner, Mauricio. Información de los Clarificantes. [En línea] 2006. [Consulta: 10 de Febrero de 2018.]. Disponible

en: http://www.cervecerosyenolooscaseros.com.ar/i nterior/todoslostitulos.php?aj_go=more\&id=114011 $5640 \&$ archive $=\&$ start_from $=\& u c a t=14 \&$. 